
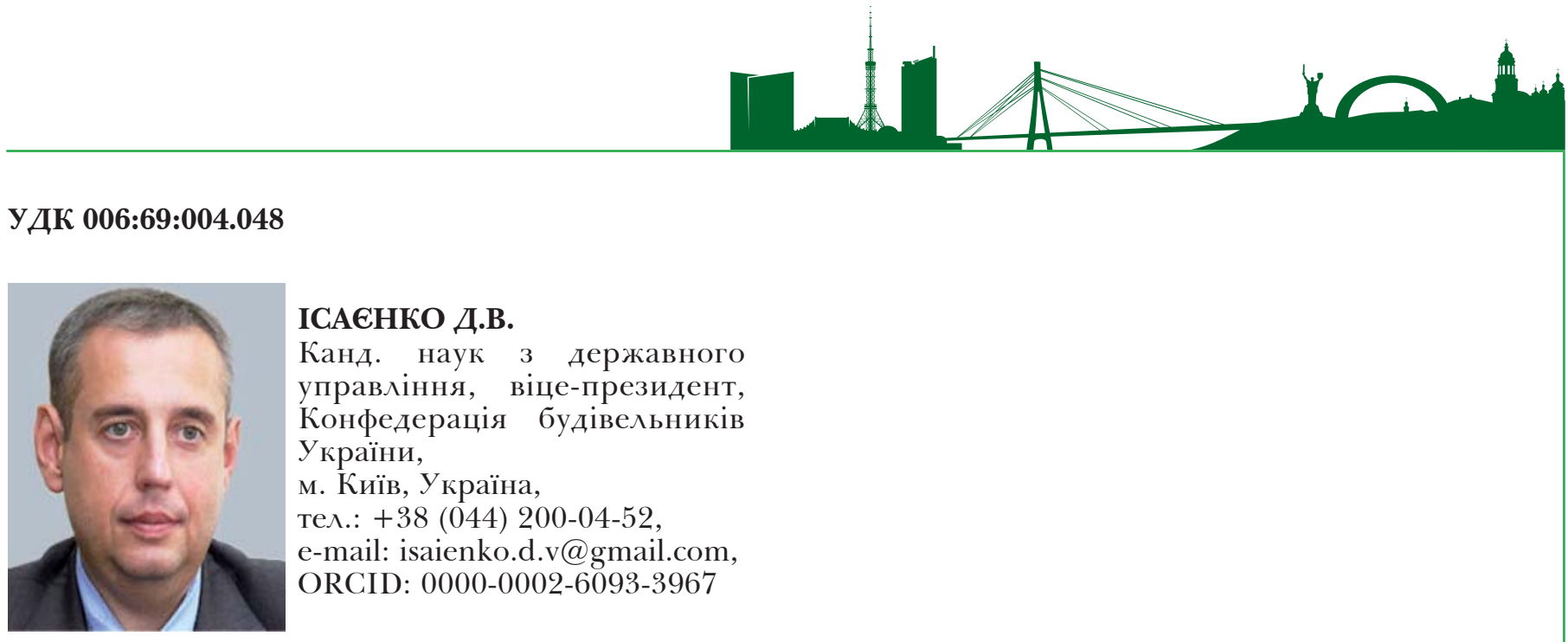

ІСАСНКО Д.В.

Канд. наук 3 державного управління, віце-президент, Конфедерація будівельників України, м. Київ, Україна, тел.: +38 (044) 200-04-52, e-mail: isaienko.d.v@gmail.com, ORCID: 0000-0002-6093-3967

\title{
СТРУКТУРА ТА ОСОБАИВОСТІ — МЕТОДОЛОГІЇ ПОБУДОВИ СИСТЕМИ ТЕХНІЧНОГО РЕГУЛЮВАННЯ В БУДІВНИЦТВІ
}

\section{АНОТАЦІЯ}

Детальний аналіз досвіду впровадження нових принципів технічного регулювання у будівництві України свідчить, що в цілому проблема наукового обгрунтування цієї діяльності є системною проблемою.

Ïї розв’язання полягає у необхідності представлення «технічного регулювання» у якості своєрідного напрямку наукових досліджень 3 подальшим створенням наукової методології цього напрямку. Таким чином, забезпечуються системні основи створення соціотехнічної системи «технічне регулювання», основною цільовою концепцією якої є запровадження «параметричного» підходу на противагу «приписувальному».

Отже, технічне регулювання як прикладний соціально-орієнтований науковий напрямок потребує створення власних методологічних наукових основ та інструментальних засобів розроблення та реалізації.

В статті детально проаналізовані основні складові ієрархічної системної методології технічного регулювання як науки, що функціонує у конфліктному науковому та адміністративному середовищах. Висвітлено особливості побудови та функціонування методології, що складається з предметно-наукової, інформаційноконфліктологічної та соціотехнічної підсистем, на основі SWOT-аналізу виявлено сучасний зріз якісного стану розвитку наукової системи «технічне регулювання» за ключовими системними показниками.

КАЮЧОВІ СЛОВА: технічне регулювання, методологія, параметричний підхід, SWOT-аналіз.

\section{СТРУКТУРА И ОСОБЕННОСТИ МЕТОДОАОГИИ ПОСТРОЕНИЯ СИСТЕМЫ ТЕХНИЧЕСКОГО СТРОИТЕЛЬСТВЕ ИСАЕНКО Д.В.}

Канд. наук по государственному управлению, вицепрезидент, Конфедерация строителей Украины, г. Киев, Украина, тел.: +38 (044) 200-04-52,

e-mail: isaienko.d.v@gmail.com,

ORCID: 0000-0002-6093-3967

\section{АННОТАЦИЯ}

Детальный анализ опыта внедрения новых принципов технического регулирования в строительстве Украины свидетельствует, что в целом проблема научного обоснования этой деятельности является системной проблемой. Ее решение заключается в необходимости представления «технического регулирования» в качестве своеобразного направления научных исследований с последующим созданием научной методологии этого направления. Таким образом, обеспечиваются системные основы создания социотехнической системы «технического регулирования», основной целевой концепцией которой является введение «параметрического» подхода в противовес «приписывающего».

Таким образом, техническое регулирование как прикладное социально-ориентированное научное направление требует создания собственных методологических научных основ и инструментальных средств разработки и реализации. В статье подробно проанализированы основные составляющие иерархической системной методологии технического регулирования как науки, которая функционирует в конфликтной научной и административной средах. Освещены особенности построения и функционирования методологии, которая состоит из предметнонаучной, информационно-конфликтологической и социотехнической подсистем, на основе SWOTанализа выявлен современный срез качественного состояния развития научной системы «техническое регулирование» по ключевым системным показателям.

КАЮЧЕВЫЕ СЛОВА: техническое регулирование, методология, параметрический подход, SWOTанализ. 
STRUCTURE AND FEATURES OF METHODOLOGY FOR THE TECHNICAL REGULATION SYSTEM DEVELOPMENT IN CONSTRUCTION

ISAIENKO D.V., PhD in Public Administration, VicePresident, Confederation of Builders of Ukraine, Kyiv, Ukraine, tel.: + 38 (044) 200-04-52, e-mail: isaienko.d.v@gmail.com, ORCID: 0000-0002-6093-3967

\section{ABSTRACT}

A detailed analysis of the experience of new technical regulation principles implementation in the construction sector of Ukraine shows that, in general, the problem of the scientific substantiation of this activity is a systemic problem. Its solution consists in the necessity of presenting «technical regulation» as a specific direction of scientific research with the subsequent creation of the scientific methodology for this direction. Thus, the systemic basis for the creation of a «technical regulation» sociotechnical system is provided, the main target concept of which is the introduction of a «parametric» approach as opposed to the «attributing» one.

Thus, technical regulation as an applied socially oriented scientific direction requires the creation ofits own methodological scientific foundations and instrumental means for the development and implementation. The main components of the hierarchical systemic methodology of technical regulation as a science, which functions in conflict scientific and administrative environments are analyzed in detail in this article. The features of the construction and operation of the methodology, which consists of the subject-scientific, information and conflict managing and sociotechnical subsystems, are highlighted; a modern assessment of the qualitative state of the «technical regulation» scientific system development by the key system indicators is revealed on the basis of the SWOT analysis.

KEY WORDS: technical regulation, methodology, parametric approach, SWOT-analysis.

\section{ПОСТАНОВКА ПРОБАЕМИ}

Впровадження сучасних концепцій та підходів у технічному регулюванні будівельної галузі України відбувається вже протягом значного періоду часу, але визначити в цілому цей процес як системний досить складно.

Серед причин такого стану відмітимо наступне:

- переважне застосування нормативної бази, що дотепер грунтується на жорстко регламентованому «приписувальному» підході;

- фрагментарність i безсистемність процесу імплементації нормативних документів, гармонізованих з нормами $\mathrm{EC}$;

- практика одночасногозастосування документів нормативної бази, окремі положення яких протирічать одне одному;

- певна неузгодженість понятійного апарату та термінології в законодавчих актах і доку- ментах нормативної бази, кон’юнктурність термінотворення;

- безсистемність дій в адміністративному середовищі соціотехнічної системи (далі CTC) технічного регулювання (далі - ТР), як приклад - функціональний розрив у повноваженнях Мінрегіону та Мінекономрозвитку, що ускладнює суб'єктне середовище системи та призводить до зниження якісного рівня створюваних норм і стандартів;

- відсутність обгрунтованої оптимальної структури взаємозв'язків та оптимізації зв'язків між суб'єктами та об'єктами технічного регулювання i, як результат, недосконалість структури суб'єктного середовища;

- невизначеність і непослідовність впровадження сучасних концепцій побудови та функціонування СТС технічного регулювання, відповідних механізмів та інструментів переходу від «приписувального» до «параметричного» підходу.

Детальний аналіз вищевказаного свідчить, що в цілому проблема науково обгрунтованого впровадження нових принципів технічного регулювання у будівництві є системною проблемою. Її розв’язання полягає у необхідності розроблення системної наукової методології створення СТС технічного регулювання, основною цільовою концепцією якої є запровадження «параметричного» підходу у технічному регулюванні.

Таким чином, очевидно, що технічне регулювання як прикладний соціально-орієнтований напрямок потребує створення власних методологічних наукових основ та інструментальних засобів розроблення та реалізації.

\section{META CTATTI}

Висвітлення принципів побудови науковообгрунтованої методології створення системи технічного регулювання в будівництві.

3 системної точки зору «технічне регулювання» як комплексний наукоємний прикладний напрямок є відкритою складною СТС, що функціонує у конфліктному зовнішньому середовищі.

Розглянемо загальну ієрархічну структуру методології прикладної наукової дисципліни, що функціонує у зовнішньому предметно-науковому та адміністративному середовищах [1]. Використовується розширене трактування поняття «методологія», доцільність використання якого визначається відкритістю напрямку, що розглядається, до зовнішнього оточення. Вказане розширене трактування полягає в наступному.

Поряд 3 предметно-науковою (змістовною та формальною) складовою, що базується на певному теоретико-методологічному ядрі науки, має бути вибудована інформаційно-конфліктологічна та соціально-технічна складові, відповідно:

а) система регулювання взаємодії науки 3 ото- 


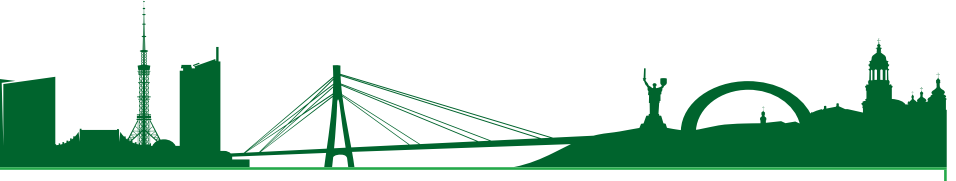

ченням, формалізації схем трансформації іiі теоретикометодологічного ядра;

б) система управління знаннями та наукою в цілому, система захисту наукового напрямку в зовнішньому середовищі.

Очевидно, що інформаційноконфліктологічний компонент методології має забезпечити цілісність і поступальний розвиток дисципліни.

В свою чергу, соціотехнічний ii аспект є засобом регулювання внутрішньої системної нестабільності та узгодження всіх напрямків розвитку, що існують фізично або потенційно в науковій дисципліні як сітковій організаційній системі.

Таким чином, методологічна система «технічного регулювання» як наукового напрямку утворена трьома супідрядними підсистемами (рис. 1).

1. Предметно-наукова niдсистема - містить структуру, зміст і визначає рівень розвитку унікального наукового продукту, що виділяе напрямок у якості самодостатньої наукової системи. Підсистема

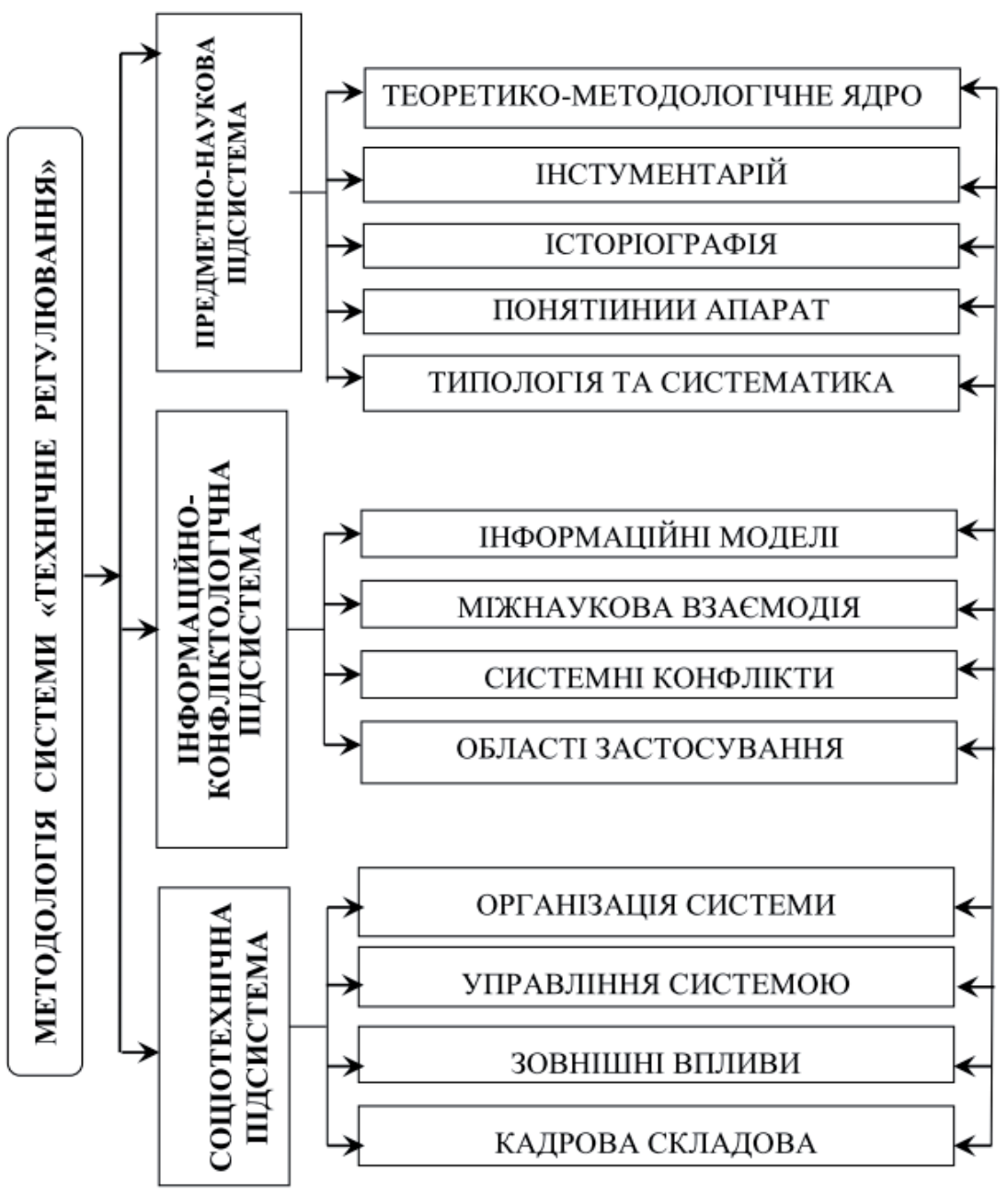

Рис. 1. . Загальна ієрархічна структура методології наукового напрямку «Технічне регулювання в будівництві» складається із:

- теоретико-методологічного ядра (далі ТМЯ), концептуальної системи, парадигми [2];

- інструментальних засобів, методів і моделей, притаманних даній науці або залучених із зовнішнього наукового оточення;

- історіографії даного напрямку (галузі), що містить упорядковану інформацію щодо генезису та знакових етапів розвитку, що принципово вплинули на сучасний науковий зміст напрямку;

- понятійного апарату, що формується як зовнішнім середовищем, так і самою системою за певними правилами та з визначеними обмеженнями [3];

- типології та систематики, що містить необхідні внутрішні іерархічні побудови наукового напрямку, класифікації та правила впорядкування елементів системи.

Слід зазначити, що на різних етапах життєвого циклу наукової системи рівень розвитку складових предметно-наукової підсистеми є різним. Так, для теоретично розвинених, «класичних» наукових дисциплін характерним $є$ існування багатьох

внутрішніх теоретичних напрямків i концепцій, розвиненість власних інструментальних і методичних засобів, стабільність понятійного апарату та ієрархічних побудов. В таких випадках в даній підсистемі виникає навіть такий структурний елемент, як «закони формування ТМЯ та інструментарію».

B нашому ж випадку має місце етап початкового формування наукової підсистеми напрямку ТР, для якого характерним є концептуальна уніфікованість (парадигма «параметричного» підходу), практична відсутність власного інструментарію, значний об’єм інформації з досвіду розвитку напрямку як в історичному, так і в регіональному вимірах $\mathrm{i}$, як результат, розбалансованість понятійного апарату [4] та відсутність чіткої типологічної побудови.

2. Інбормаційно-конббліктологічна складова визначає інформаційну структуру напрямку, стан іï розвитку та специфіку конфліктної взаємодії як елементів всередині системи, так і взаємодію системи 3 зовнішнім науковим та науково-адміністративним оточенням. Інформаційно-конфліктологічну підсистему складають:

- інформаційні моделі - інформаційна структура наукового продукту, яку зручно пред- 
ставити моделлю Г. Доброва [5], в якій наукова інформація (I0) визначається трьома компонентами: фактичний матеріал (F0); інструментальні засоби, методи та моделі (М0); теоретична платформа даної науки (C0);

- міжнаукова взаємодія - правила раціонального дистанціювання та продуктивної взаємодії напрямку з науковим оточенням (асиміляція, синтезування галузей, суміжність наук тощо);

- системні конфлікти - дослідження конфліктів внутрішнього та зовнішнього порядку на всіх рівнях ієрархії системи та етапах іiі життєвого циклу. Конфліктологічний аналіз внутрішніх елементів системи «технічне регулювання» $є$ надзвичайно важливим, оскільки він фактично визначає раціональну структуру відношень суб'єктів і об'єктів та модель формування системи нормативних вимог в технічному регулюванні [6-8];

- область застосування - дослідження та прогностичне моделювання розвитку області застосування практичного (фактичного) продукту як результату системного функціонування СТС ТР.

Зазначимо, що інформаційно-конфліктологічна підсистема забезпечує обгрунтування безконфліктності внутрішньої структури ТР та 6 своєрідним механізмом перенесення наукоємних результатів предметно-наукової підсистеми ТР до середовища впровадження.

3. Соціально-технічна підсистема забезпечує реалізацію організаційно-управлінських i технологічних аспектів впровадження науково обгрунтованих результатів функціонування системи ТР в середовищі впровадження. Підсистема складається 3 наступних елементів:

- організація системи - визначає принципи та правила побудови організаційних структур системи технічного регулювання в актуальному стані, в процесі трансформації до системного впровадження параметричного підходу, в прогностичних моделях розвитку будівельної галузі тощо;

- управління системою-визначає раціональні управлінські підходи та моделі управління системою та іiі функціонування на всіх етапах життєвого циклу, включаючи процеси внутрішніх структурних перетворень (реінжиніринг);

- зовнішні впливи - досліджуе стан, трансформації та характер взаємодії зовнішнього адміністративного оточення, в якому функціонує система (органи державного управління, недержавні структури, законодавча база, пов'язана з системою технічного регулювання тощо);

- кадрова складова - забезпечує професійну кадрову підтримку процесу створення об'єктів технічного регулювання шляхом створення відповідних напрямків підготовки у профільних закладах вищої освіти та системі післядипломної освіти. Тут слід відзначити певний досвід КНУБА у розвитку даного напрямку, а саме, відкриття на будівельному факультеті напрямку підготовки фахівців «Стандартизація та сертифікація в будівництві».

Для аналізу сучасного якісного стану (рівня системності) методологічної парадигми наукового напрямку «технічне регулювання» скористаємось методом SWOT-аналізу, використавши методику, запропоновану в [1].

Проаналізуємо елементи методології за системними ознаками, присвоївши кожному елементу умовну оцінку $(1,0,-1)$, що мають в конкретному випадку наступний зміст:

- наявність типологічного та понятійнотермінологічного впорядкування методології - (створена, в стадії створення, відсутня);

- системна довершеність - (є цілісною системою, реалізована на рівні підсистем, системність відсутня);

- стадія детермінованого циклу та динаміка розвитку - (зростання, стабільність, редукція);

- рівень дійсної та потенційної конфліктності - (безконфліктна, локально конфліктна, конфліктна);

- відкритість до змін (консерватизм системи) (відкрита, нейтральна, консервативна);

- загальні перспективи розвитку - (високі, помірні, низькі).

Результати аналізу представлені в табл. 1. Знаком (*) відзначено тривіальні значення показників.

Загальний розподіл оцінок у рейтинговій таблиці свідчить про актуальний стан розвитку методології технічного регулювання як про слабо впорядковану та слабо структуровану систему 3 потенційно високим рівнем конфліктності, але значним наукоємним потенціалом і відкритістю до наповнення, що знаходиться на висхідному циклі розвитку.

\section{ВИСНОВКИ}

Створення системної методології технічного регулювання як наукоємного прикладного напрямку вирішує не тільки проблему його впорядкування, а й встановлює взаємозв'язок ієрархічно пов'язаних підсистем системи ТР та відкриває можливості до розвитку інструментально-методичних складових системи. Дослідження інформаційно-конфліктологічних 
Таблиця 1. Оцінка якісного рівня методології

\begin{tabular}{|c|c|c|c|c|c|c|c|}
\hline $\begin{array}{l}\text { № } \\
\Pi / \Pi\end{array}$ & ЕЛЕМЕНТИ ПІДСИСТЕМ & 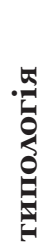 & 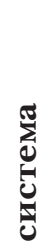 & 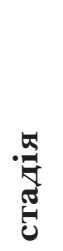 & 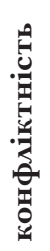 & 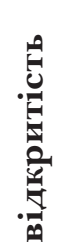 & 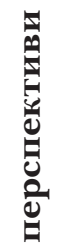 \\
\hline 1 & 2 & 3 & 4 & 5 & 6 & 7 & 8 \\
\hline 1 & Історіографія & 1 & 0 & 1 & 0 & -1 & -1 \\
\hline 2 & Понятійний апарат & -1 & 0 & 1 & -1 & 1 & 1 \\
\hline 3 & Типологія та систематика & $*$ & -1 & 0 & 0 & 0 & 0 \\
\hline 4 & Інструментарій & -1 & 0 & 1 & 1 & 1 & 1 \\
\hline 5 & $\begin{array}{l}\text { Теоретико-методологічне } \\
\text { ядро }\end{array}$ & 0 & 0 & 1 & 1 & 0 & 0 \\
\hline 6 & Інформаційні моделі & 1 & 1 & 0 & 0 & 1 & 0 \\
\hline 7 & Міжнаукова взаємодія & 0 & 0 & 1 & -1 & 1 & 1 \\
\hline 8 & Області застосування & -1 & 0 & 1 & -1 & 0 & 0 \\
\hline 9 & Системні конфлікти & 1 & 1 & 0 & $*$ & 0 & 0 \\
\hline 10 & Організація системи & 0 & 0 & 1 & -1 & 1 & 1 \\
\hline 11 & Управління системою & 0 & 0 & 1 & -1 & 1 & 1 \\
\hline 12 & Зовнішні впливи & 0 & -1 & 0 & -1 & 1 & 0 \\
\hline \multirow[t]{2}{*}{13} & Кадрова складова & 1 & 0 & 1 & 1 & 1 & 1 \\
\hline & Загальний рейтинг & 1 & $\mathbf{0}$ & +9 & -3 & +7 & +5 \\
\hline
\end{tabular}

коведение / Г.М. Добров. - Киев: Наукова думка, 1970. - 320 с.

6. ІсаєнкоД.В.Об'єктитехнічного регулювання у будівництві. Міжвідомчий науковотехнічний зб. / Д.В. Ісаєнко // Технічна естетика і дизайн. Київ: КНУБА, 2017 р.

7. Ісаєнко Д.В. Суб’єкти технічного регулювання у буд-ві / Д.В. Ісаєнко // Містобудування та територіальне планування. 2018. - Вип. 66. - С. 223-231.

8. Ісаєнко Д.В. Базова модель побудови системи визначення нормативних вимог у буд-ві / Д.В. Ісаєнко // Містобудування та територіальне планування. 2018. - Вип. 68. - С. 209-219.

\section{REFERENCES}

1. Ploskyi, V.O.(2008). Thestructure of applied geometry methodology and its SWOT-analysis. Bull. of Kherson National Techn. Univ., 3 (31), 398 - 401 [in Ukrainian].

2. Holton, G. (1981). Thematic analysis of science. M.: Progress [in Russian].

та організаційно-технічних аспектів методології створює умови для безконфліктного, безпечного та поступального розвитку напрямку в зовнішньому середовищі.

\section{БІБЛІОГРАФІЧНИЙ СПИСОК}

1. Плоский В.О. Структура методології прикладної геометрії та іï SWOT-аналіз / В.О. Плоский // Вестн. Херсонского нац. технического ун-та. - Херсон, 2008. - Вып. 3 (31). - C. 398-401.

2. Холтон Дж. Тематический анализ науки / Дж. Холтон. - М.: Прогресс, 1981. -384 с.

3. Ісаєнко Д.В. Терміни та визначення як підгрунтя забезпечення формування законодавчої та нормативної бази інвестиційної діяльності, гармонізованої 3 нормами законодавства Европейського Союзу / Д.В. Ісаєнко // Містобудування та територіальне планування. - Київ: КНУБА, Міносвіти. - 2016. - Вип. 62, Ч. 1. - С. 228-234.

4. Ісаєнко Д.В. Про деякі негативні наслідки некоректного застосування термінів та визначення понять в містобудівному та спеціальному законодавстві / Д.В. Ісаєнко // 36. наукових пр. «Будівельне право: проблеми теорії і практики». - Київ - Тернопіль: Матеріали Першої науково-практ. конф. (3 листопада 2017 р.) - КНУБА: Економічна думка, 2017. - С. 27-33.

5. Добров Г.М. Наука о науке: введ. в общее нау-
3. Isaienko, D.V. (2016). Terms and definitions as the basis for ensuring the formation of legislative and regulatory framework for the investment activity harmonized with the EU standards and regulations. Mistobuduvannia ta terytorialne planuvannia, 62, Part 1, 228-234 [in Ukrainian].

4. Isaienko, D.V. (2017). On some negative consequences of incorrect terms use and concepts definitions in urban planning and specific legislation. Construction law: Problems of theory and practice. Proceedings: Kyiv - Ternopil: The First scientific and practical conf. (November 3, 2017), 27-33. K.: KNUBA. Ekonomichna dumka [in Ukrainian].

5. Dobrov, H.M. (1970). Science about science: Introduction to the general science studies. K.: Naukova dumka [in Russian].

6. Isaienko, D.V. (2017). Technical aesthetics and design. Objects of technical regulation in constr. K.: KNUBA [in Ukrainian].

7. Isaienko, D.V.(2018). Subjects of techn. regulation in constr. Mistobuduvannia ta terytorialne planuvannia, 66, 223-231 [in Ukrainian].

8. Isaienko, D.V. (2018). The base model of the system formation for determining the normative requirements in constr. Mistobuduvannia ta terytorialne planuvannia, 68, 209-219 [in Ukrainian].

Стаття надійшла до редакції 12.02.2019 р. 